\title{
New Records and Notes on Hawaiian Marine Benthic Chlorophyta, including Pseudochlorodesmis abbreviata (Gilbert), n. comb. (Udoteaceae) and Cladophora luxurians (Gilbert), n. comb. (Cladophoraceae) ${ }^{1}$
}

\author{
Isabella A. Abbott and Fobn M. Huisman ${ }^{2}$
}

\begin{abstract}
Morphology, taxonomy, and nomenclature of three species of $\mathrm{Ha}$ waiian green algae (Chlorophyta) are examined. Udotea? abbreviata Gilbert is shown to be incorrectly placed in that genus and more appropriately allied to Pseudocblorodesmis. The complex nomenclatural relationships of Cladophora tildeniae Brand in Tilden, Cladophora tildeniae Brand, and Cladophora bawaiiana Tilden are described, with the latter deemed the appropriate name and Microdictyon japonicum var. laxum Gilbert regarded as a synonym. An examination of Cladophoropsis luxurians Gilbert has shown it to have delayed formation of transverse walls at the bases of lateral branches, a feature not consistent with inclusion in Cladopboropsis but rather with Cladophora. The new combinations Pseudocblorodesmis abbreviata (Gilbert) Abbott \& Huisman and Cladophora luxurians (Gilbert) Abbott \& Huisman are made, and nine species of marine benthic Chlorophyta are newly recorded for the Hawaiian Islands.
\end{abstract}

The MARINE BENTHIC algal flora of the $\mathrm{Ha}$ waiian Islands has, historically and recently, received a great deal of attention, both from indigenous Hawaiians as a source of food and from phycologists as constituting a particularly rich biodiversity and as a source of many interesting and novel taxa. A recent outcome of this attention was the publication of $M a$ rine red algae of the Hawaiian Islands (Abbott 1999), the first major algal flora for the central Pacific and the first of a series that eventually also will include the brown and green seaweeds.

During preparatory research for the Chlorophyta volume we encountered three species with a confused nomenclatural and taxonomic past, as well as documented nine new records for the Hawaiian Islands, all of which we report here.

${ }^{1}$ Research supported by the David and Lucile Packard Foundation. Manuscript accepted 17 October 2002.

${ }^{2}$ Department of Botany, University of Hawai' $i$ at Mānoa, 3190 Maile Way, Honolulu, Hawai'i 96822.

Pacific Science (2003), vol. 57, no. 3:275-285

(C) 2003 by University of Hawai'i Press

All rights reserved

\section{MATERIALS AND METHODS}

Plants were preserved either in formalin/ seawater or as dried herbarium specimens and on microscope slides. Materials for slide preparations were stained with aniline blue and mounted in water for photography, and then infused with corn syrup (Karo, CPC International) solution to make permanent mounts. Pyrenoids were observed by staining with Lugol's solution. Specimens were examined with a microscope (Olympus BX3) and photographed using a digital camera (Olympus D11). Herbarium abbreviations follow Holmgren et al. (1990) with the exception of IA, which refers to the I. Abbott collection housed at the Department of Botany, University of Hawai'i at Mānoa.

RESULTS

Pseudochlorodesmis abbreviata (Gilbert) Abbott \& Huisman, n. comb.

Basionym: Udotea? abbreviata Gilbert, Pac. Sci. $16: 142$, fig. $8 a-c$ (1962).

TYPE SPECIMEN: Gilbert 9511, on calcareous rocks, $1-1.5 \mathrm{~m}$ below surface on reef opposite Marine Biological Laboratory, Waikīkī, Honolulu, O'ahu, 21 April 1959 (n.v., fide Gilbert 1962). This specimen cannot be 
located and in its absence we lectotypify the species with Gilbert's fig. $8 a-c$ (reproduced as our Figure 1).

SPecimens examined: Moloka'i: Kalauрара, в іsн 653286 (Figure 2).

DISTRIBUTION: Hawaiian Islands.

HABIT AND VEGETATIVE STRUCTURE: The following description is based on the recently collected specimens. Dimensions given in parentheses are from Gilbert (1962).

Plants filamentous, siphonous; with a prostrate basal portion of limited extent and upright, dichotomously branched fronds in which the branches lie in one plane; prostrate portion irregularly branched and coralloid; upright portion to $5 \mathrm{~mm}(5 \mathrm{~mm})$ tall, with a monosiphonous stalk to $2.6 \mathrm{~mm}$ in length and $75-135$ (72) $\mu \mathrm{m}$ diam., with upper siphons 45-65 $\mu \mathrm{m}$ diam., 45-50 (25-38) $\mu \mathrm{m}$ diam. near apices; branching above strictly dichotomous, with $100-650 \mu \mathrm{m}$ between successive dichotomies; chloroplasts numerous, ovoid to lenticular, approximately 5 by $2 \mu \mathrm{m}$.

REMARKS: Gilbert (1962) described $U d o-$ tea? abbreviata from specimens collected from Waikīki, O'ahu Island. The plants were siphonous, with an irregularly branched basal portion and upright fronds consisting of a monosiphonous stipe and dichotomously divided upper portion, with the forks all lying in one plane (Gilbert 1962: fig. 8a-c, reproduced here as Figure $1 a-c)$. Gilbert was clearly uncertain as to the correct generic placement of this species, comparing it first with representatives of Flabellaria $(=U$ dotea) and Udotea before settling on the latter with "real uncertainty" (Gilbert 1962:143) and noting in particular that the basal stalk and branching in one plane were similar to features of Udotea javensis (Montagne) Gepp \& Gepp (now Rbipidosiphon javensis Montagne). The calcified thallus and constricted siphons of $U$. javensis, however, were sufficiently different in his opinion to warrant the description of a new species for the Waikiki plants. Udotea? abbreviata has not been reported since its original collection and thus has not been critically appraised; the apparent loss of type material is an additional difficulty. The species is clearly incorrectly placed in Udotea, a genus whose members are calcified and have multistratose blades, with lateral appendages on the siphons of many blades and all stalks (Littler and Littler 1990), and, for the reasons just given, also does not belong in Rhipidosiphon.

We have examined specimens (Figure 2) collected in recent years from Moloka i Island that seem be in almost every way referable to Udotea? abbreviata, although the dimensions of the recent collections vary slightly from those given by Gilbert. The upright portions of the plants are comparable with those described by Gilbert, but the new specimens have a slightly more extensive basal portion that is irregularly swollen and has occasional constrictions.

Two species, in separate genera, are relevant to a consideration of the proper placement of $U$.? abbreviata. Its basal portion is strongly reminiscent of that found in $P s e u$ docblorodesmis parva Gilbert (1962), the type specimen of which was collected from the same locality as U.? abbreviata. The genus Pseudocblorodesmis was originally described by Børgesen (1925:77) for P. furcellata (Zanardini) Børgesen, based on Bryopsis furcellata Zanardini (1843) from the Mediterranean, although Børgesen based the genus concept on material from the Canary Islands. Defining characters of the genus include a basal portion that is irregularly swollen and with constrictions, and an upright frond that lacks constrictions at the infrequent branch points. These features are also found in U.? $a b-$ breviata, although it differs in that the upright siphons are distinctly dichotomously branched and the constrictions are not present at the bases of the upright fronds. However, Segawa (1941) reported regularly dichotomously branched $P$. furcellata from Japan, and Kraft (2000) recorded the same species from Lord Howe Island, southwestern Pacific, that also seemingly lacked basal constrictions.

The dichotomously branched siphons of $U$.? abbreviata are also strongly reminiscent of those of Derbesia? fastigiata Taylor (1928:94, plate 11: figs. 1-3), a species originally described from Florida but also reported from several other tropical locations, including Hawai'i (Gilbert 1962) and the Southwest 

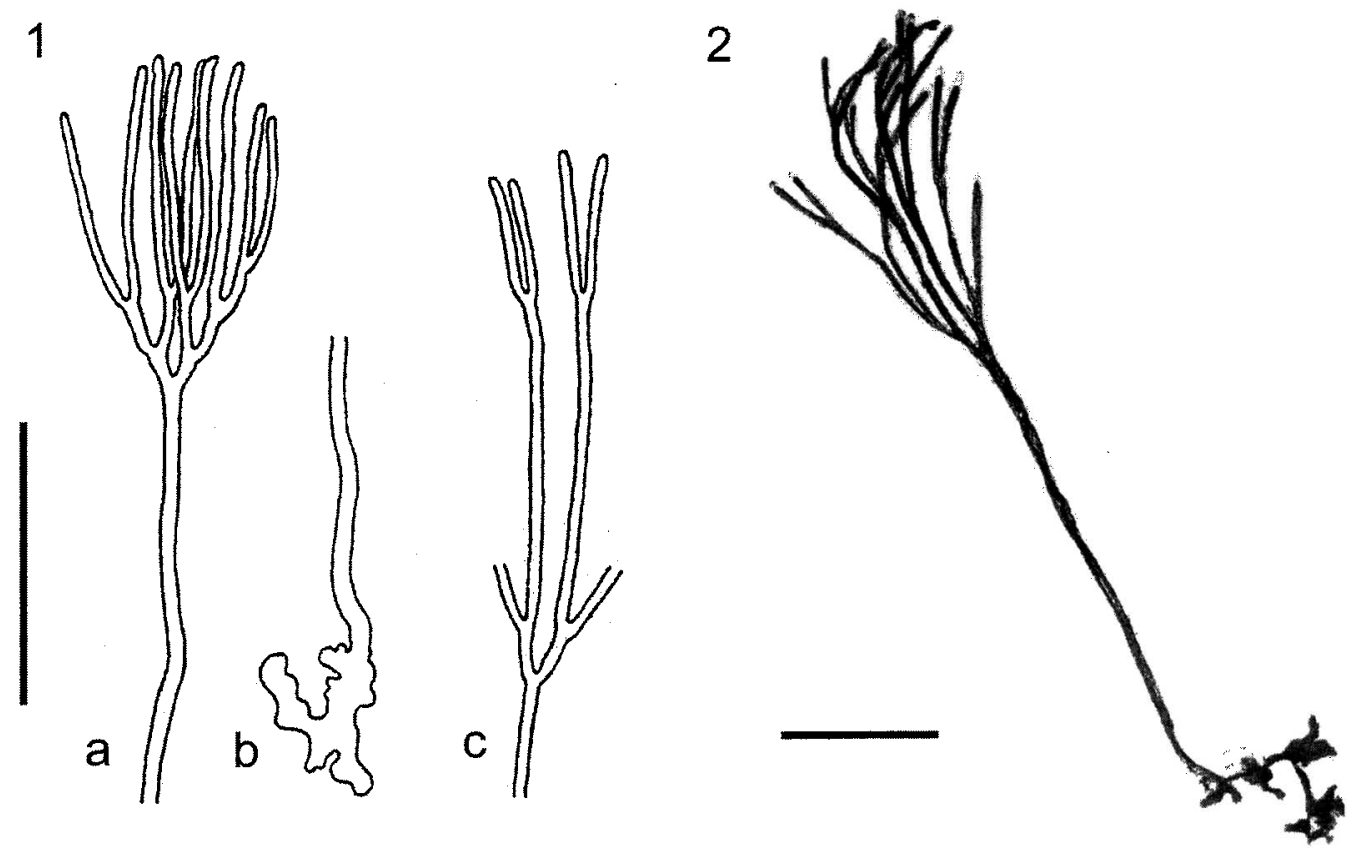

Figures 1-2. Pseudochlorodesmis abbreviata (Gilbert) Abbott \& Huisman, n. comb. 1. Gilbert's illustrations from the protologue: $a, b$, Upper and lower portions of the same plant. $c$, Upper portion of a plant to illustrate that dichotomies may be close or distant (caption from Gilbert 1962); scale $=1 \mathrm{~mm}$. 2. Comparable specimen from Moloka'i, BISH $653286 ;$ scale $=500 \mu \mathrm{m}$.

Pacific Ocean (Silva et al. 1996, Phillips 1997). This species was included in Derbesia with some doubt by Taylor (1928). Derbesia fastigiata differs from U.? abbreviata in forming an extensive prostrate system composed of interwoven siphons that are not irregularly swollen (Gilbert 1962). The genus Derbesia differs from Pseudocblorodesmis in the lack of amyloplasts (colorless plastids) in the former and their presence in the latter, but we were unable to ascertain with certainty whether the recent specimens of $U$. ? abbreviata contained amyloplasts. Some colorless plastids were observed, but these were mixed among more numerous green plastids and could possibly be artifacts of preservation.

From our examination of U.? abbreviata, we have concluded that its uncalcified thallus and unadorned, dichotomous siphons preclude its placement in Udotea, and we feel that the species is more appropriately placed in Pseudocblorodesmis. There is a strong possibil- ity that $U$. abbreviata represents a growth form of $P$. furcellata, but until more specimens can be examined we prefer to keep them separate.

\section{Cladopbora bawaiiana Tilden}

American algae 7, nos. 615, 616 (1909).

Synonyms: Cladophora tildenii Brand, Beih.

Bot. Centralbl. 18:186-187, plate VI, figs.

24-27 (1904); nom. inval., non $C$. tildenii

Brand in Tilden, American algae 6, no. 541

(1902) $[=$ C. canalicularis (Roth) Kützing, fide Tilden 1909].

Microdictyon japonicum var. laxum Gilbert, Pac. Sci. 16:139, figs. 5C,D; 6 (1962).

LeCTotype: Brand, 1904, plate VI, figs. 24-27 (reproduced as our Figure 3).

SPECIMENS EXAMINED: O'ahu: Ka'ena Point, вish 651438; Keawa'ula (Yokohama Bay), BIsH 653055; Lāna'i lookout, Hālona, BISH 648526. Moloka'i: Kalaekapu Point, BISH 628824; Moku Islet site LVII, BISH 

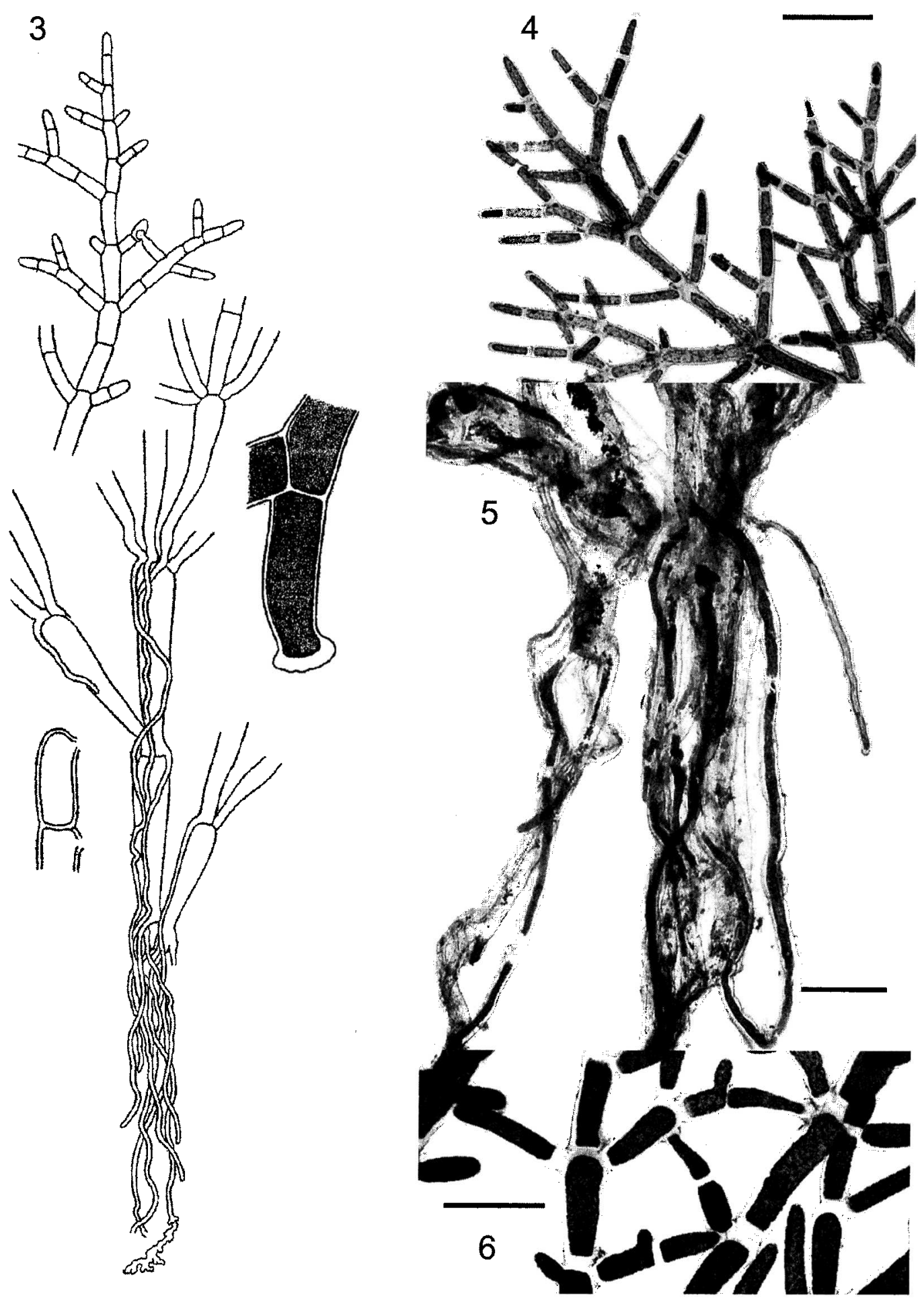
625020; Kalaupapa, north of lighthouse, в IS H 653276. Hawai'i: Lili'uokalani Gardens Pond, BISH 636077.

Distribution: Hawaiian Islands.

HABIT AND vegetative STRUCtuRE: Plants $1.5-3 \mathrm{~cm}$ tall, dark green, with several fanlike fronds arising from a common rhizoidal holdfast; each frond with lower cells bearing strong, nonseptate, uniseriate rhizoids (Figure 5) from the basal poles, these intertwining and directed downward for 3-4 $\mathrm{mm}$; lower axial cells cylindrical, 80-200 $\mu \mathrm{m}$ diam., length: width $=2-6: 1$, with apical ends frequently widening and becoming clavate (Figure 3); upper cells of axes 50-80 $\mu \mathrm{m}$ diam.; apical cells with broadly rounded ends. Branching opposite or flabellate, with most nodes initially bearing 2 or 4 opposite lateral branches (Figures 3, 4), these eventually becoming indistinguishable from primary axes belonging to a flabellate node of five branches; lateral branches bearing 1- to 4celled branchlets either adaxially or abaxially, with each of the penultimate orders bearing 1- to 2-celled branchlets, either oppositely or occasionally secundly. Intercalary divisions in primary axes present, resulting in internodes 2 cells long, but these obscured by rapid initiation of adventitious laterals that often remain short, 1-2 cells long, with those in the inner, lower portions of some plants occasionally forming terminal adhesions to a cell of an adjacent branch (Figure 6).

REPRODUCTION: Brand (1904) illustrated fertile zooidangia, each with a raised, distal pore (see our Figure 3). Identical reproductive structures were observed in several specimens (e.g., вISH 653276, в ISH 648426) from recent collections.

REMARKS: The name Cladophora tildeniae Brand (as "tildenii") first appeared in Tilden's American algae, no. 541 (1902), but it was 2 yr later before a complete description was given. Brand (1904:186, figs. 24-27, reproduced as our Figure 3) highlighted the following three features that he considered diagnostic of the species: (1) a fan-shaped thallus; (2) conspicuous rhizoids that are not produced laterally from the axis but as basipetal projections from lower cells of the main axis; and (3) scattered adhesions of apical cells to lower-order branch cells, as in Microdictyon. Unfortunately, none of these features is displayed by the specimens that were circulated in Tilden's American algae exsiccatae (as no. 541) under the name of Cladopbora tildenii Brand. In fact, this number represents a freshwater species of Cladophora collected from Pearl City, O'ahu, that Brand (1904) designated as Cladophora (Spongomorpba) longiarticulata Nordstedt var. valida Brand but that was later identified by Tilden as C. canalicularis (Roth) Kützing, a species that is currently considered to be a synonym of C. glomerata (Linnaeus) Kützing (Guiry and Nic Dhonncha 2002). A specimen of this entity from Tilden's collection (no. 541 ) is preserved in the Bishop Museum (no. 531869), Honolulu, and has been examined. It is a sparsely branched plant, with subdichotomies every 1-9 cells; the cells are $270-540 \mu \mathrm{m}$ long by $135-160 \mu \mathrm{m}$ diam. and tapering to $45 \mu \mathrm{m}$ diam. near the apex. The morphology of no. 541 is thus clearly not the same as that described by Brand for Cladophora tildeniae (1904), and the specimen is probably correctly identified as $C$. glomerata, a species that is common in Hawaiian streams (A. R. Sherwood, pers. comm.). We conclude therefore that Cladophora tildeniae Brand in Tilden (1902) is not the same as Cladopbora tildeniae Brand (1904). Moreover, because Cladophora tildeniae Brand (1904) is a later homonym of Cladophora tildeniae Brand in Tilden (1902), the name has to be rejected.

Tilden realized that an error had been made, and in Fascicle 7 of American algae (1909) she placed C. tildeniae Brand (1904:86, referred to as "in manuscript" by Tilden; non C. tildeniae Brand in Tilden 1902) in synonymy with her new Cladophora bawaiiana Til-

Figures 3-6. Cladophora bazuaiiana Tilden. 3. The lectotype illustrations, reproduced from Brand (1904). 4. Apex of plant showing initiation of lateral branches, в гін 648426; scale $=500 \mu \mathrm{m}$. 5 . Descending rhizoids forming a dense, entwined mass, вısн 648426; scale $=250 \mu \mathrm{m}$. 6 . Lateral branches forming attachments with nearby filaments, BISH $625020 ;$ scale $=250 \mu \mathrm{m}$. 


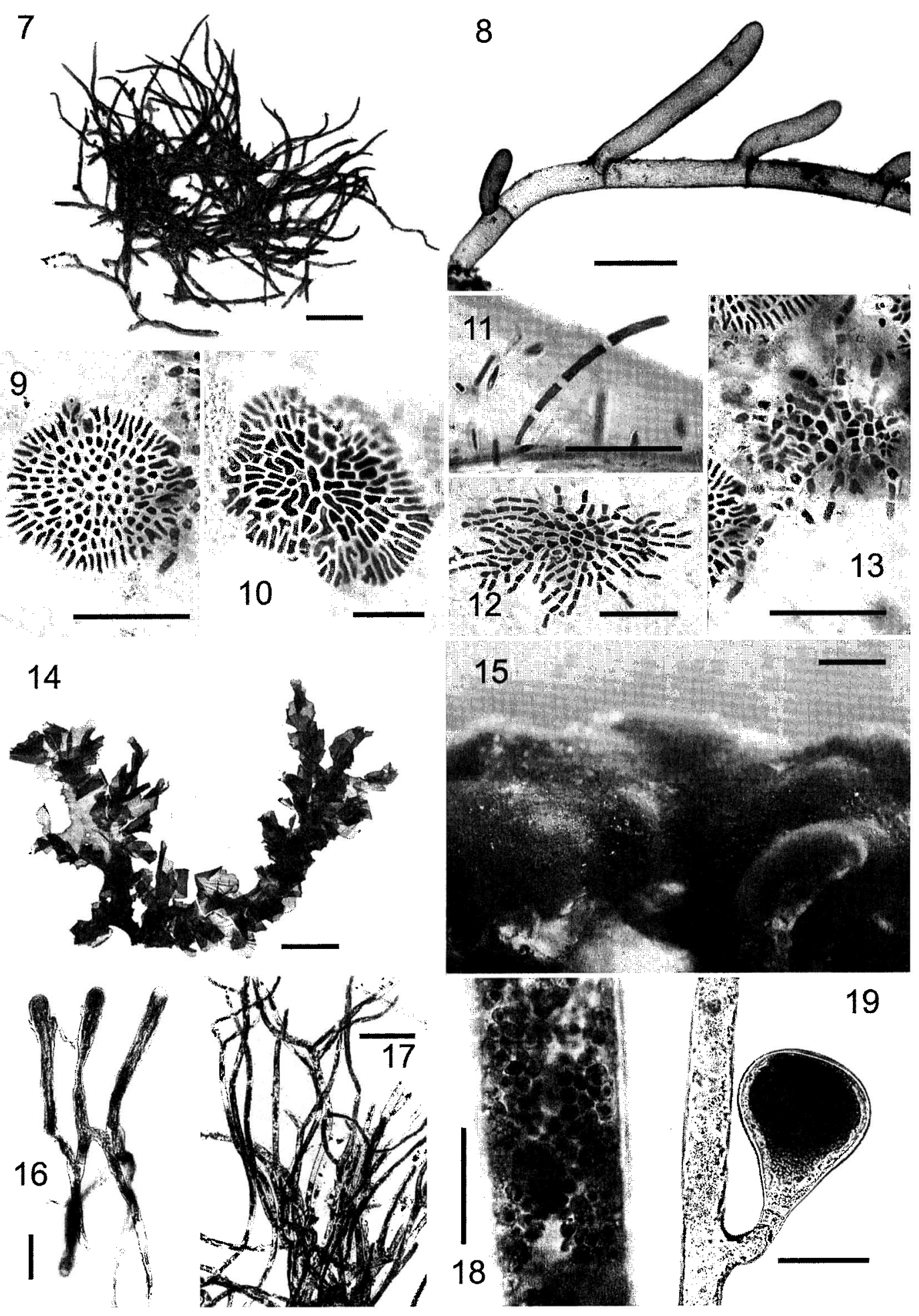


den (nos. 615-616). Although not explicitly stated, the implication of Tilden's treatment of this species is that $C$. hawaiiana was a substitute name for $C$. tildeniae sensu Brand. The type of this species is therefore the Brand specimens, but unfortunately these seem to be lost, so here we lectotypify the species with Brand's figures (1904, figs. 24-27, reproduced as our Figure 3), which are sufficiently detailed to characterize the species.

To further complicate matters, the specimens distributed by Tilden as $C$. bawaiiana (no. 615) do not agree with Brand's description (P. Silva, pers. comm.), and their identity is yet to be ascertained. These specimens were collected at La $\bar{a}^{-} \mathrm{ie}, \mathrm{O}^{6} \mathrm{ahu}$ Island, a marine locality.

Two additional taxa are relevant to a consideration of $C$. bawaiiana. The first, Microdictyon japonicum var. laxum, was described by Gilbert (1962:139, figs. 5C,D; 6C) for specimens from Maui, Hawaiian Islands. Gilbert's variety is considered by us to represent $C$. bawaiiana. Although the planar branching and secondary adhesions of this variety undoubtedly led Gilbert to place it in Microdictyon, we feel that the rarity of secondary adhesions more strongly allies it to Cladophora. A second species with some similarities to C. hawaiiana is Rbipidopbyllon reticulatum (Askenasy) Heydrich (type locality: Dirk Hartog Island, Western Australia). Børgesen's (1924) depiction of this species from Easter Island, however, indicates that the lateral filaments are issued from the apices of the subtending cells and are always upwardly directed, unlike the spreading laterals of Cla- dopbora bawaiiana. In addition, the lateral branches of Rbipidopbyllon reticulatum apparently always arise in one plane (Borgesen 1924:252), whereas occasional branches of $C$. bawaiiana do not.

Cladophora bawaiiana also displays many of the features of the widespread Willeella ordinata Børgesen, 1930 (see Itono 1970, van den Hoek and de Rios 1972). Willeella was reduced to a (possibly monospecific) section of Cladopbora by van den Hoek (1982), but recently Silva et al. (1996) maintained it at the genus level, in anticipation of future molecular data that they suggest will support the recognition of segregate genera. Similarities between the two species include their branching pattern and the production of closely adpressed, descending rhizoids from the bases of lower lateral branches. However, whereas Cladophora hawaiiana does produce several laterals of equal length from each node, these do not arise synchronously (as do those of Willeella). Kraft and Millar (in Kraft 2000:548) recently described a species of Cladophora (C. willeelloides Kraft \& Millar) that has characteristics similar to those of $C$. $b a$ waiiana, and we follow their interpretation that such plants should be maintained in Cladophora. In addition to the nonsynchronous production of laterals, those authors highlighted several additional characters of $C$. willeelloides that differed from Willeella ordinata, including paired, nonrostrate ostioles in zooidangia. Zooidangia in Cladophora bawaiiana, as in $C$. willeelloides, produce raised pores, further reinforcing the distinction between the two species and Willeella. Clado-

Figures 7-19. 7. Herbarium specimen of Cladophora luxurians (Gilbert) Abbott \& Huisman, n. comb., BISH 515693; scale $=1 \mathrm{~cm} .8$. Cladopbora huxurians, detail showing initiation of lateral branches and delayed formation of cross-walls; scale $=2 \mathrm{~mm}$. 9. Ulvella lens $\mathrm{P}$. Crouan \& H. Crouan, showing roughly circular outline (specimens depicted in Figures 9-13 are all growing on the surface of Rbizoclonium grande, $\mathrm{BISH} 771278$ ); scale $=40 \mu \mathrm{m}$. 10. Ulvella setchellii Dangeard, with elongate cells; scale $=40 \mu \mathrm{m}$. 11. Uronema marina Womersley, showing unbranched arcuate filament; scale $=40 \mu \mathrm{m}$. 12. Stromatella monostromatica (Dangeard) Kornmann \& Sahling, with filaments coalescing in the center but free at margins; scale $=40 \mu \mathrm{m}$. 13. Entocladia viridis Reinke, with free filaments and cells with pyrenoids; scale $=40$ $\mu \mathrm{m}$. 14. Ulva taeniata (Setchell) Setchell \& Gardner, showing ruffled margins of thallus, IA $17613 ; \mathrm{scale}=2 \mathrm{~cm}$. 15 . Codium picturatum F. F. Pedroche \& P. C. Silva, growing closely adpressed to the substratum, in $28794 ;$ scale $=2 \mathrm{~mm}$. 16. Codium picturatum utricles, IA 28794; scale $=100 \mu \mathrm{m}$. 17. Derbesia tenuissima (Moris \& De Notaris) Crouan, thallus habit, IA 28048; scale $=300 \mu \mathrm{m}$. 18. Derbesia tenuissima, stained with Lugol's solution, showing pyrenoids in the plastids, IA 28048; scale $=40 \mu \mathrm{m}$. 19. Derbesia tenuissima, detail of gametangium with double septa at base, IA 28048; scale $=100 \mu \mathrm{m}$. 
pbora bawaiiana differs from $C$. willeelloides in the presence of occasional anastomoses between branches and absence of long internodes. Intercalary divisions in $C$. bawaiiana are followed rapidly by the initiation of lateral branches, such that internodes are generally only one-celled (rarely up to four cells long); in contrast, internodes in C. willeelloides can be up to 14 cells long (Kraft 2000).

\section{Cladophora luxurians (Gilbert) Abbott \&} Huisman, n. comb.

Basionym: Cladopboropsis luxurians Gilbert, Pac. Sci. 16:136 (1962).

Synonym: Cladophora (Aegagropila) montagnei Kützing var. waianaeana Brand, Beib. Bot. Centralbl. 18:185-186, plate V, figs. 2123 (1904).

SPECIMENS EXAMINed: Kaua'i: Kīpū Kai, вIsII 531172. O'ahu: Kāne'ohe Bay, вısн 525117; Ka'ena Point, віsн 516991. Moloka'i: (as C. luxurians) в вsн 515671. Maui: (Gilbert as C. luxurians) віsн 515693; Hāna Bay, IA 14564.

Distribution: Hawaiian Islands; possibly more widespread.

habit AND vegetative structure: Plants in mostly decumbent clumps $1-5 \mathrm{~cm}$ across (Figure 7), composed of coarse, branched filaments; branching sparse or profuse, usually secund and irregular; cross-wall formation at base of laterals delayed (Figure 8); apices often becoming decumbent and reattached, some with small specialized hapteroid cells at apices; filaments (250) 400-700 $\mu \mathrm{m}$ diam.; rhizoids, where developed laterally, about one-half the diameter of adjacent branch, long, mostly nonseptate but with basal crosswalls.

REMARKS: Cladophoropsis luxurians is a common and conspicuous species on $\mathrm{Ha}-$ waiian reef flats, where it forms mats of imbricating, bright green filaments. Characteristic features of the species include its arcuate filaments with often-secund lateral branches (Figures 7,8) and the formation of secondary attachments at the apices of branches. The species does not belong in Cladophoropsis, however, in which the defining feature is the persistent open connection between lateral branches and the subtending cell. An examination of $C$. luxurians reveals that, although initially in open connection to the bearing cell, cross-walls are subsequently formed at the bases of lateral branches (Figure 8), a feature also illustrated by Gilbert (1962: fig. 3) and by Brand (1904) in his description of $C$. montagnei var. waianaeana, which we consider to be synonymous with C. luxurians. Van den Hoek and Womersley (1984) reported that in many species of Cladophora section Repentes crosswall formation is delayed, as is also the case in C. luxurians.

Cladophoropsis luxurians seems to be closely related to Cladopbora catenata (Linnaeus) Kützing as described and illustrated by van den Hoek and Chihara (2000: fig. 18). That species also forms dense cushions, with stiff, branched, often curved stolonlike filaments. Secondary rhizoids and attachments are also formed at the apices. Cladopbora catenata appears to differ from $C$. luxurians in the smaller diameter of cells, with those of the former reaching a maximum diameter of $510 \mu \mathrm{m}$ (van den Hoek and Chihara 2000:46), whereas cells of C. luxurians can be up to $700 \mu \mathrm{m}$ diam. Payri et al. (2000) recorded Cladophoropsis luxurians from French Polynesia, but their description indicates that cross-walls are not formed and thus does not agree with $C$. luxurians as known from Hawaiian collections. Hawaiian specimens clearly referable to $C$. luxurians were also identified as Cladophora montagneana var. waianaeana by Brand (1904), but the species is not at all similar to Cladophora montagneana Kützing [as depicted by van den Hoek and Womersley (1984)] and that placement cannot be supported. Our results indicate that $C$. lux urians cannot be maintained in Cladophoropsis and is more appropriately allied with Cladophora.

\section{New Records of Cbloropbyta for the Hawaiian Islands}

The following species are newly recorded for the Hawaiian Islands. In some cases they represent widespread but cryptic species, generally only noticed during microscopical examinations of larger algae. 
Ulvella lens $\mathrm{P}$. Crouan \& H. Crouan

Ann. Sci. Nat. Bot. 12:288 (1859).

Figure 9

Distribution: Widespread in tropical and warmer seas.

\section{Ulvella setchellii Dangeard}

Bull. Soc. Bot. Fr. 78 : 318 (1931).

Figure 10

DISTRIBUTION: Widespread in tropical to colder seas.

Uronema marina Womersley

Marine Bentbic Flora Southern Australia 1 : 131 (1984).

Figure 11

distribution: Hawai'i; Australia.

Stromatella monostromatica (Dangeard) Kornmann \& Sahling

Helgol. Meeresunters. 36:12 (1983).

Figure 12

Distribution: Widespread in tropical to colder seas.

Entocladia viridis Reinke

Bot. Z. 37 : 476 (1879).

Figure 13

Distribution: Widespread; recorded from the Tropics to polar regions.

REMARKS: These five species form crusts or filaments that grow on or course through the cuticles of larger, generally green, algae. They are probably widespread but are commonly overlooked due to their habitat and microscopic size. These records are of specimens observed on a single host plant, Rbizoclonium grande Børgesen (BISH 771278), but the species are known to occur on a variety of hosts (Kraft 2000). Ulvella lens (Figure 9) and $U$. setchellii (Figure 10) form roughly circular thalli on the surface of the host cuticle, differing in the radially elongate cells of the latter. Uronema marina (Figure 11) occurs as short, unbranched filaments. Stromatella monostromatica (Figure 12) has filaments coalesced near the center but free at the margins, and Entocladia viridis (Figure 13) has mostly free filaments that grow within the cuticle of the host. In addition, Entocladia differs from Stromatella in the presence of several pyrenoids (as opposed to one) per plastid.

Ulva taeniata (Setchell) Setchell \& Gardner

Univ. Calif. Publ. Bot. 8:286 (1920).

Figure 14

SPECimens examined: Kaua'i: Po'ipū Beach, IA 13514. Maui: Hāna Bay, IA 14568. Distribution: Widespread in the Pacific and Indian Oceans.

REMARKS: Ulva taeniata is a distinctive species with narrow, straplike branches and conspicuously ruffled margins. Although the common (in the Hawaiian Islands) Ulva fasciata has similarly narrow branched axes and may appear to have ruffled margins, the latter feature is not characteristic of the majority of populations; moreover, the bases of $U$. fasciata are formed by a broadened portion (the remnants of the original flat blade when the plant was young) from which the divided portions project like fingers, whereas in $U$. taeniata there are no broadened portions of the single blades, nor are there any unruffled margins.

\section{Cladopboropsis sundanensis Reinbold}

Nuova Notar. ser. 16, p. 147 (1905).

SPecimens examined: Kaua'i: Kīpū Kai, BIsn 53113. O'ahu: Waikīkī, IA 19812. Moloka'i: віSн 91964. Kaho'olawe: $\mathrm{Pu}^{\prime} u$ Koa'e, IA 21116a. Maui: Ka'uiki Head, IA 18027. Hawai'i: South Kona, в IsH 515727.

distribution: Widespread in the Pacific and Indian Oceans.

REMARKS: The specimens reported here are included in Cladophoropsis sundanensis based on their dimensions (with filaments generally $80-100 \mu \mathrm{m}$ in diam.) and thallus structure. In Cladophoropsis the lateral branches remain in open connection with the bearing cell (i.e., no cellular cross-wall is formed). Cladopboropsis sundanensis is commonly reported in the Indo-Pacific, but Kraft (2000) questioned whether many of these records refer to the same species because not all agree with the type description.

Codium picturatum F. F. Pedroche \& P. C. Silva

Acta Bot. Mex. 35:2, figs. 1-5 (1996).

Figures 15, 16 
SPECIMENS examined: Hawai'i: Punalu'u, IA 28794.

DISTRIBUTION: Hawai'i; southern part of Gulf of California; tropical Pacific Mexico; Panama; Colombia; Galápagos.

REMARKs: Codium picturatum was described by Pedroche and Silva (1996) for plants from the Pacific coast of tropical America. It is a distinctive species due to its extremely thin crustose habit (Figure 15), unusual utricle morphology (Figure 16), and tortuous medullary filaments. The Hawaiian plants were closely adpressed to basalt rock at less than $1 \mathrm{~m}$ depth and could easily have been overlooked or mistaken for the more common Codium arabicum Kützing. The identity of the Hawaiian specimens was ascertained by P. Silva (pers. comm., 2002).

\section{Derbesia tenuissima (Moris \& De Notaris) Crouan}

Fl. Finist., p. 133 (1867).

Figures 17-19

SPECIMENS EXAMined: Maui: Makena, iA 28048.

distributron: Northeast Atlantic; Mediterranean; western Pacific Ocean; Indian Ocean.

REMARKS: The specimens reported here are included under Derbesia tenuissima due to their similarities with the descriptions given by Kobara and Chihara (1981), Womersley (1984), and Burrows (1991). The double septa below the sporangia (Figure 19) are considered to be distinctive of $D$. tenuissima according to Womersley (1984), but various authors have also included specimens displaying such a condition in the closely related Derbesia marina (Lyngbye) Solier (e.g., Kraft 2000) and thus the character is not regarded as critical in species determination. Womersley (1984) regarded the presence of double septa at the bases of vegetative laterals as distinctive of $D$. marina, and such septa occasionally are present in the Hawaiian plants, which therefore display apparently characteristic features of two species. Both Kobara and Chihara (1981) and Womersley (1984), however, regard the presence or absence of pyrenoids in the chloroplast as the critical feature for separating $D$. tenuissima (with pyrenoids) from $D$. marina (without). The specimens reported here were preserved in formalin and the pyrenoids were not obvious, but staining with Lugol's solution clearly showed pyrenoids within each plastid (Figure 18). The plastids were smaller than generally described, but this is most likely due to preservation, which can cause the plastids to become rounded when they are usually lenticular (Womersley 1984). Other vegetative and reproductive features are compatible with $D$. tenuissima.

\section{ACKNOWLEDGMENTS}

We thank Paul Silva (University of California at Berkeley), who identified the specimen of Codium picturatum, and Lynn Hodgsen (University of Hawai ${ }^{6}$ ), who collected it. Gerry Kraft (University of Melbourne) critically read the manuscript and suggested numerous improvements.

\section{Literature Cited}

Abbott, I. A. 1999. Marine red algae of the Hawaiian Islands. Bishop Museum Press, Honolulu.

Børgesen, F. 1924. Marine algae from Easter Island. Pages 247-309 in C. Skottsberg, ed. The natural history of Juan Fernandez and Easter Island. Vol. 2. 50 figs. Uppsala. 1925. Marine algae from the Canary Islands, especially from Teneriffe and Gran Canaria. I. Chlorophyceae. K. Dan. Vidensk. Selsk. Biol. Medd. 5 (3): 1-123, 49 figs.

-1930. Some Indian green and brown algae especially from the shores of the Presidency of Bombay. J. Indian Bot. Soc. 9:151-174.

Brand, F. 1904. Über die Anheftung der Cladophoraceen und über verschiedene polynesische Formen dieser Familie. Beih. Bot. Centralbl. 18 (Abt. 1): 165-193, plates $\mathrm{V}, \mathrm{VI}$.

Burrows, E. M. 1991. Seaweeds of the British Isles. Vol. 2. Chlorophyta. Natural History Museum Publications, London.

Gilbert, W. J. 1962. Contribution to the marine Chlorophyta of Hawaii, I. Pac. Sci. 16:135-144. 
Guiry, M. D., and E. Nic Dhonncha. 2002. AlgaeBase. Worldwide Web electronic publication. www.algaebase.org [3 October 2002].

Hoek, C. van den. 1982. A taxonomic revision of the American species of Cladophora (Chlorophyceae) in the North Atlantic Ocean and their geographic distribution. Verh. K. Ned. Akad. Wet. Afd. Natuurk. Tweede Reeks Sect. 78. 236 pp.

Hoek, C. van den, and M. Chihara. 2000. A taxonomic revision of the marine species of Cladophora (Chlorophyta) along the coasts of Japan and the Russian Far-East. Nat. Sci. Mus. Tokyo, Monogr. 19:1-242.

Hoek, C. van den, and N. de Rios. 1972. Willeella ordinata Boergesen, 1930 (Chlorophyceae, Cladophorales): First record for America. J. Phycol. 8:207-208.

Hoek, C. van den, and H. B. S. Womersley. 1984. Genus Cladopbora Kuetzing 1843: 262, nom. cons. Pages 185-213 in H. B. S. Womersley. The marine benthic flora of southern Australia. Part I. Government Printer, South Australia.

Holmgren, P. K., N. H. Holmgren, and L. C. Barnett. 1990. Index herbariorum. Part I: The herbaria of the world. 8th ed. New York Botanical Garden, New York [Regnum Vegetabile, Vol. 120].

Itono, H. 1970. On the two species of genus Willeella of southern Japan. Bull. Jpn. Soc. Phycol. 18:127-130.

Kobara, T., and M. Chihara. 1981. Laboratory culture of two species of Derbesia (Class Chlorophyceae) in Japan. Bot. Mag. Tokyo 94:1-10.

Kraft, G. T. 2000. Marine and estuarine benthic green algae (Chlorophyta) of Lord
Howe Island, south-western Pacific. Aust. Syst. Bot. 13:509-648.

Littler, D. S., and M. M. Littler. 1990. Systematics of Udotea species (Bryopsidales, Chlorophyta) in the tropical western Atlantic. Phycologia 29:206-252.

Payri, C., A. de R. N'Yeurt, and J. Orempuller. 2000. Algae of French Polynesia. Au Vent des Iles. Editions, Tahiti.

Pedroche, F. F., and P. C. Silva. 1996. Codium picturatum sp. nov. (Chlorophyta), una especie extraordinaria del Pacifico tropical Mexicano. Acta Bot. Mex. 35:1-8.

Phillips, J. A. 1997. Algae. Pages 223-240 in R. J. F. Henderson, ed. Queensland plants: Names and distribution. Queensland Herbarium, Department of Environment, Indooroopilly, Queensland.

Segawa, S. 1941. New or noteworthy algae from Izu I. Sci. Pap. Inst. Algol. Res. Fac. Sci. Hokkaido Imp. Univ. 2:251-271, plates LV-LVIII.

Silva, P. C., P. Basson, and R. Moe. 1996. Catalogue of benthic marine algae of the Indian Ocean. Univ. Calif. Publ. Bot. 79. 1279 pp.

Taylor, W. R. 1928. The marine algae of Florida with special reference to the Dry Tortugas. Carnegie Inst. Washington Publ. 379: $(\mathrm{v}+) 219$ pp.

Tilden, J. E. 1902. American algae. Century 6, nos. 501-600. Minneapolis.

2. 1909. American algae. Century 7, nos. 601-650. Minneapolis.

Womersley, H. B. S. 1984. The marine benthic flora of southern Australia. Part I. Government Printer, South Australia.

Zanardini, G. 1843. Saggio di classificazione naturale delle Ficee. Venice. 